\title{
Investigation of Association between Genetic Polymorphisms of MMP2, MMP8, MMP9 and TIMP2 and Development of Varicose Veins in the Slovak Population - Pilot Study
}

\author{
Jana MAZUCHOVÁ ${ }^{1}$, Erika HALAŠOVÁ ${ }^{1,2}$, Július MAZUCH ${ }^{3}$, Miroslava ŠARLINOVÁ ${ }^{2}$, \\ Vanda VALENTOVÁ ${ }^{1}$, Mária FRANEKOVÁ ${ }^{1}, \breve{S}_{\text {tefan ZELNÍK }}^{4}$, Katarína KRKOŠKOVÁ ${ }^{5}$, \\ Karol JAVORKA ${ }^{6}$, Martin PÉČ ${ }^{1}$, Marián GRENDÁR ${ }^{2}$
}

${ }^{1}$ Department of Medical Biology, Jessenius Faculty of Medicine, Comenius University in Bratislava, Martin, Slovak Republic, ${ }^{2}$ Biomedical Center Martin, Department of Medical Biology, Jessenius Faculty of Medicine, Comenius University in Bratislava, Martin, Slovak Republic, ${ }^{3}$ Clinic of Surgery and Transplant Center, University Hospital in Martin, Martin, Slovak Republic, ${ }^{4}$ ŽILPO Ltd., Private Healthcare Facility, Žilina, Slovak Republic, ${ }^{5}$ GynMart Ltd., Gynecology Clinic, Martin, Slovak republic, ${ }^{6}$ JAVORKA Ltd., Gynecology, Obstetrics and Immunoalergology Clinic, Ružomberok, Slovak Republic

Received March 30, 2020

Accepted October 6, 2020

\begin{abstract}
Summary
Matrix metalloproteinases (MMPs) are a family of zinc-dependent metalloendopeptidases that degrades extracellular matrix (ECM) components. MMPs are associated with venous wall remodelling, proliferation, migration, phenotypic and functional transformation of vascular smooth muscle cells and ECM organization under the physiological and pathophysiological conditions. We investigated possible association of genetic promoter polymorphisms of MMP2 (rs243866), MMP8 (rs11225395), MMP9 (rs3918242) and TIMP2 (rs8179090) to varicose veins development in the Slovak population. Genomic DNA from 276 Slovak individuals (138 cases, 138 controls) was genotyped for selected SNPs (rs243866, rs11225395, rs3918242 and rs8179090) using the PCR-RFLP analysis. The data were analysed by chi-squared $\left(X^{2}\right)$ test, logistic regression, and Mann-Whitney test. The risk of varicose veins development was evaluated in dominant, codominant and recessive genetic models. The statistical evaluation of selected polymorphisms in patients in all three genetic models has not shown a significant risk of varicose veins development. Our study has not shown the association between selected polymorphisms and increased risk of varicose veins development in Slovak population. More evidence with broaden sample size is needed.
\end{abstract}

\section{Key words}

Varicose veins - Genetic polymorphisms • Matrix Metalloproteinases • MMP2, MMP8, MMP9, TIMP2

\section{Corresponding author}

J. Mazuchová, Department of Medical Biology, Jessenius Faculty of Medicine, Malá Hora 4, 03601 Martin, Slovakia. E-mail: jana.mazuchova@uniba.sk

\section{Introduction}

Chronic venous disease (CVD) including varicose veins belong to the most frequent diseases in developed countries in Europe and USA and affect from third to half of the population, especially women (Štvrtinová and Čelovská 2017). The socioeconomic importance of CVD is due to the cost of diagnostics and management, lowered quality of life, especially in higher clinical stages and loss of working days (Rabe and Pannier 2010). According to internationally used CEAP classification $(\mathrm{C}=$ Clinical picture, $\mathrm{E}=$ Etiology, $\mathrm{A}=$ Anatomy, $\mathrm{P}=$ Pathophysiology), $\mathrm{CVD}$ has seven stages (C0-C6). $\mathrm{C} 0$ indicates no visible signs of CVD or palpable varicose veins; $\mathrm{C} 1$, telangiectasia (spider veins); $\mathrm{C} 2$, varicose veins; $\mathrm{C} 3$, oedema; $\mathrm{C} 4$, skin damage due to

PHYSIOLOGICAL RESEARCH • ISSN 1802-9973 (online) 
varicose veins or venous reflux - hyperpigmentation, eczema, lipodermatosclerosis or atrophie blanche; C5, healed venous leg ulcer; $\mathrm{C} 6$, open and active venous leg ulcer (Salmhofer 2016).

The vein wall structure and function are partially regulated by matrix metalloproteinases (MMPs) (Chen et al. 2017). Matrix metalloproteinases (MMPs) are a family of zinc-dependent metalloendopeptidases that degrade extracellular matrix (ECM) components and nonECM molecules including receptors, growth factors, cytokines and chemokines, all of which are determinants of the tissue microenvironment (Lauhio et al. 2016, Kunt et al. 2015, Shiomi et al. 2010).

The activity of MMPs is tightly regulated by a family of endogenous inhibitors termed as tissue inhibitors of metalloproteinases (TIMPs) (Johnson 2017). Both MMPs and TIMPs regulate the homoeostasis of the extracellular matrix. MMPs are involved in the degradation of the extracellular matrix components, while TIMPs influence vascular remodelling, causing an altered vein elasticity (Ellinghaus et al. 2017). MMPs can also influence the bioactive molecules present on the cell surface through the G-protein-coupled receptors (GPCRs) and regulate the cell environment (MacColl and Khalil 2015).

Multiple studies have suggested that imbalance between MMPs and TIMPs may contribute to the formation and development of varicose veins (BadierCommander et al. 2000, Aravind et al. 2010, Kalinin et al. 2016, Johnson 2017, Hu et al. 2019). Results of these studies are inconsistent, disregard anatomical region the sample comes from and clinical stage of the disease (Serralheiro et al. 2017). Vascular remodelling represents the compensatory mechanism for the veins to adapt to pathological conditions such as venous hypertension and hypoxia (Zhao et al. 2020).

Elastin and collagen are important for the structural integrity of the vein wall (MacColl and Khalil 2015). In varicose veins decreased amount of elastin, and also structurally changed elastin were observed. MMP-2 (gelatinase A) and MMP-9 (gelatinase B) are the main enzymes involved in elastin assembly (Görmüs et al. 2014, Nagase et al. 2006). MMP-2 can cleave many collagen substrates (I, II, III, IV, V, VII, X, XI, gelatine) and non-collagen substrates including aggrecan, elastin, fibronectin, laminin, nidogen, proteoglycan link protein and versican. Also, MMP-9 can degrade collagen type IV, V, VII, X, XIV, gelatine, and the same non-collagen substrates as gelatinase A. Similarly, MMP-8 (collagenase-2) breaks down collagen I, II, III, V, VII, VIII, X, gelatine, aggrecan, elastin, fibronectin, laminin, and nidogen (MacColl and Khalil 2015).

Different TIMPs inhibit different MMPs better than others, e.g. TIMP-1 inhibits MMP-1, MMP-3, MMP-7, and MMP-9 more effectively, whereas TIMP-2 inhibits MMP-2 better than TIMP-1. TIMP-2 is the only member of TIMP family that specifically interacts with both MT1-MMP and pro-MMP-2 on the cell surface, therefore functions as both MMP inhibitor and MMP activator (Bourboulia and Stetler-Stevenson 2010). Moreover, TIMP-2 has the ability to suppress the proliferation of endothelial cells directly (Seo et al. 2003).

The aim of the study was to investigate whether selected polymorphisms of $M M P 2, M M P 8, M M P 9$ and TIMP2 genes are associated with a risk of varicose veins development in the Slovak cohort. All selected polymorphisms have the potential to influence gene expression.

\section{Methods}

\section{Patients and controls}

An approval for the study was granted by the Ethics Committee of Jessenius Faculty of Medicine in Martin, and all participants provided informed written consent before their inclusion. Participants in the study were of Caucasian origin recruited from the Clinic of Surgery and Transplant Center (University Hospital in Martin), ZILPO Ltd., GynMart Ltd. and JAVORKA Ltd. from October 2013 to December 2019. A $5 \mathrm{ml}$ sample of venous peripheral blood was collected into EDTA tube. A total of 138 subjects (48 males and 90 females) diagnosed by qualified physicians as varicose veins patients based on the CEAP classification (C1-C3 stage) were recruited into the study. Varicose veins were surgically verified. At the same time, a total of 138 healthy individuals of comparable age and gender with no evidence of venous disease, venous ulcers, thrombophlebitis, thrombosis or history of cancer were enrolled into this study. Case-control groups were made up from individuals with a similar age and gender distribution and medians did not differ significantly (Table 1).

\section{Genomic DNA extraction}

Genomic DNA extraction was done by using PureLink ${ }^{\circledR}$ Genomic DNA Kit (Invitrogen ${ }^{\mathrm{TM}}$, Thermo 
Fisher Scientific, New York, USA) from EDTA peripheral blood samples. Extracted DNA was stored at $-20^{\circ} \mathrm{C}$ until the analysis.

\section{SNP genotyping}

DNA was used for genotyping of the four selected SNPs (rs243866, rs11225395, rs3918242 and rs8179090) by using the PCR-RFLP method according to the modified protocols of Harendza et al. 2003, Xu et al. (2011), Izakovičová Hollá et al. (2012), and Kunt et al. (2015). The SNPs were identified from the database of single nucleotide polymorphisms from the National Centre for Biotechnology Information (NCBI) available online at http://www.ncbi.nlm. nih.gov/snp/.

All PCRs were performed in a $25 \mu$ reaction mixture containing: $150 \mathrm{ng}$ of the template DNA, $12.5 \mu \mathrm{l}$ DreamTaq Green PCR Master Mix (2X), $0.25 \mu \mathrm{M}$ of each primer and nuclease-free water. Technical details of PCR-RFLP are shown in Table 2.

Approximately $20 \%$ of the samples were chosen at random for second PCR-RFLP analysis to confirm the genotypes from the amplified PCR product.

Table 1. Gender and age distribution in cases and controls.

\begin{tabular}{lccc}
\hline & Cases & Controls & P \\
\hline Number (males/females) & $138(48,90)$ & $138(48,90)$ \\
Mean age & 41.13 & 40.89 & $0.9189^{\mathbf{a}}$ \\
$(95 \%$ CI) (Range, SD) & $(39.1-43.2)(17-65, \pm 12.3)$ & $(39.1-43.2)(17-65, \pm 12.7)$ & \\
Males & 37.23 & 36.23 & $0.6601^{\mathbf{a}}$ \\
$(95 \%$ CI) (Range, SD) & $(34.0-40.5)(18-59, \pm 11.1)$ & $(32.6-39.5)(16-59, \pm 11.4)$ & \\
Females & 43.21 & 43.37 & $0.8953^{\mathbf{a}}$ \\
$(95 \% C I)$ (Range, SD) & $(40.6-45.8)(17-65, \pm 12.4)$ & $(40.7-46.1)(17-65, \pm 12.8)$ & \\
\hline
\end{tabular}

CI - confidence interval, ${ }^{\mathbf{a}}-$ Mann-Whitney U test.

Table 2. Technical details of PCR-RFLP analysis.

\begin{tabular}{|c|c|c|c|c|}
\hline \multirow{2}{*}{ Polymorphism } & PCR primers $\left(5^{\prime} \rightarrow 3^{\prime}\right)$ & \multirow{2}{*}{$\begin{array}{l}\text { Restriction } \\
\text { enzyme }\end{array}$} & \multirow{2}{*}{$\begin{array}{c}\text { Gel } \\
\text { electrophoresis }\end{array}$} & \multirow{2}{*}{$\begin{array}{l}\text { Fragment identifying } \\
\text { genotypes (bp) }\end{array}$} \\
\hline & Thermal cycling parameters & & & \\
\hline \multirow[t]{2}{*}{$\begin{array}{l}M M P 2 \\
(\mathrm{rs} 243866)\end{array}$} & $\begin{array}{l}\text { F: ACCAGACAAGCCTGAACTTGTCTGA } \\
\text { R: TGTGACAACCGTCTCTGAGGAATG }\end{array}$ & PagI & $2 \%$ agarose gel & $\begin{array}{c}\mathrm{WT}=542 \\
\text { Het }=542+460+82 \\
\text { Var }=460+82\end{array}$ \\
\hline & \multicolumn{4}{|c|}{$95^{\circ} \mathrm{C}-5 \mathrm{~min} ; 35$ cycles: $95^{\circ} \mathrm{C}-30 \mathrm{~s}, 70^{\circ} \mathrm{C}-30 \mathrm{~s}, 72^{\circ} \mathrm{C}-60 \mathrm{~s} ; 72^{\circ} \mathrm{C}-5 \mathrm{~min}$} \\
\hline \multirow[t]{2}{*}{$\begin{array}{l}M M P 8 \\
(\text { rs11225395) }\end{array}$} & $\begin{array}{l}\text { F: CTGTTGAAGGCCTAGAGCTGCTGCTCC } \\
\text { R: GATCTTCTCTTCAAACTCTACCC }\end{array}$ & SfcI & $1 \%$ agarose gel & $\begin{array}{c}\mathrm{WT}=893+74 \\
\text { Het }=967+893+74 \\
\text { Var }=967\end{array}$ \\
\hline & \multicolumn{4}{|c|}{$94{ }^{\circ} \mathrm{C}-5 \mathrm{~min} ; 34$ cycles: $94{ }^{\circ} \mathrm{C}-40 \mathrm{~s}, 61.5^{\circ} \mathrm{C}-45 \mathrm{~s}, 72{ }^{\circ} \mathrm{C}-60 \mathrm{~s} ; 72{ }^{\circ} \mathrm{C}-10 \mathrm{~min}$} \\
\hline \multirow[t]{2}{*}{$\begin{array}{l}M M P 9 \\
(\mathrm{rs} 3918242)\end{array}$} & $\begin{array}{l}\text { F: GCCTGGCACATAGTAGGCCC } \\
\text { R: CTTCCTAGCCAGCCGGCATC }\end{array}$ & PaeI & $2.5 \%$ agarose gel & $\begin{array}{c}\text { WT }=436 \\
\text { Het }=436+242+194 \\
\text { Var }=242+194\end{array}$ \\
\hline & \multicolumn{4}{|c|}{$94{ }^{\circ} \mathrm{C}-4$ min; 35 cycles: $94{ }^{\circ} \mathrm{C}-60 \mathrm{~s}, 70{ }^{\circ} \mathrm{C}-60 \mathrm{~s}, 72{ }^{\circ} \mathrm{C}-60 \mathrm{~s} ; 72{ }^{\circ} \mathrm{C}-5 \min$} \\
\hline \multirow[t]{2}{*}{$\begin{array}{l}\text { TIMP2 } \\
\text { (rs8179090) }\end{array}$} & $\begin{array}{l}\text { F: CGTCTCTTGTTGGCTGGTCA } \\
\text { R: CCTTCAGCTCGACTCTGGAG }\end{array}$ & Eco88I & $10 \%$ PAGE gel & $\begin{array}{c}\text { WT }=230+51+23 \\
\text { Het }=253+230+51+23 \\
\text { Var }=253+51\end{array}$ \\
\hline & $95^{\circ} \mathrm{C}-5 \mathrm{~min} ; 30$ cycles: $95^{\circ} \mathrm{C}-30 \mathrm{~s}, 65.5^{\circ} \mathrm{C}$ & $-30 \mathrm{~s}, 72{ }^{\circ} \mathrm{C}$ & $60 \mathrm{~s} ; 72{ }^{\circ} \mathrm{C}-5 \mathrm{~min}$ & \\
\hline
\end{tabular}

F - forward primer, R - reverse primer, WT - wild type, Het - heterozygote, Var - variant. 


\section{Data analysis and statistical tests}

To analyze the variance in selected risk factors between the case and control group, Fisher's exact test was used. The chi-squared $\left(\chi^{2}\right)$ test with Yates's continuity correction was used to evaluate differences from HardyWeinberg equilibrium and the independence of genotype and allele frequencies. Association of genotype combinations with the development of varicose veins was estimated by Fisher's exact test. The risk of varicose veins development was evaluated in codominant, dominant and recessive genetic models. Additionally, the odds ratios (ORs) and $95 \%$ confidence intervals (CIs) were calculated to identify the strength of association between selected SNP and varicose veins development. To verify the genotype distribution independence from age and gender chi-squared independence $\left(\chi_{\text {indep }}^{2}\right)$ test and logistic regression were used. A value of $\mathrm{P}<0.05$ was considered statistically significant. The genotyping data were analysed by InStat (GraphPad Software, Inc.; Version 3.01) data analysis software and online statistical software package StatPages.net (https://statpages.info/). Sample size determination was performed in $\mathrm{R}$ ( $\mathrm{R}$ Core Team 2020) ver. 4.0.2, using library pwr (Champely 2020). The power of 0.8 and significance level of 0.05 were used in the sample size determination for both the chi-squared test and the test of equality of two population proportions.

\section{Results}

We have conducted a case-control study determining whether selected genetic polymorphisms MMP2 (rs243866), MMP8 (rs11225395), MMP9 (rs3918242) and TIMP2 (rs8179090) present in the promoter regions were associated with varicose veins development and affect the occurrence and clinical stage of varicose veins in the Slovak population.

Similar age distribution was observed between the patients and healthy controls. However, family predisposition, history of thrombosis and thrombophlebitis, and working habits and smoking were different. Family history was positive in 106 (76.81\%) cases in the patient's group vs. $20(14.49 \%)$ cases in the control group. A positive history of thrombosis was observed in $23(16.67 \%)$ patients, thrombophlebitis in $5(3.62 \%)$ patients. More patients with varicose veins declared a prolonged standing, sitting or their combination during working hours, compared to the control group. Smoking was observed more often in the control group than in the group of varicose veins patients $(28.99 \%$ vs. $15.94 \%)$. The studied population characteristics are shown in Table 3.

The genotype frequencies in patients and controls were in Hardy-Weinberg equilibrium. The frequency of minor allele A for the polymorphism of the MMP2 gene (rs243866) was 0.25 in patients, and 0.28 in controls. Minor allele frequency (T allele) in polymorphism MMP8 (rs11225395) was in patients 0.44 , while in controls 0.46 . The frequency of variant $\mathrm{T}$ allele for MMP9 polymorphism (rs3918242) was 0.17 in patients versus 0.16 in controls. Variant allele $\mathrm{C}$ of TIMP2 polymorphism (rs8179090) was detected in less than $1 \%$ of all tested individuals. This frequency of the variant allele in the Slovak population was too low, therefore obtained results were not statistically processed. Minor allelic frequencies did not differ significantly between patients and controls. Distribution of alleles and genotypes were similar in comparison to average data for European Caucasian populations according to the Ensembl database (https:/www.ensembl.org/ index.html).

The evaluation of selected polymorphisms in patients in codominant, dominant and recessive genetic models did not show a significantly changed risk of varicose veins development. A similar distribution of genotypes of polymorphisms MMP2 (rs243866), MMP8 (rs11225395), and MMP9 (rs3918242) was observed in both studied groups. These results are summed in Table 4. This is a pilot study. To reach the desired statistical power of 0.8 the total sample size needs to broaden (calculation of sample size determination is visible in Table $4-\mathrm{SSD}$ ).

Additional analysis performed after classification of patients and controls based on sex, age, genetic predisposition, and clinical stage revealed no statistical significance ( $\mathrm{p}>0.05$; data not shown).

In contrast, risk assessment of selected genotypic combinations showed more interesting results. Genotype combination CC+TT of rs11225395 and rs3918242 polymorphisms indicates higher risk of varicose veins $(\mathrm{OR}=11.00 ; 95 \% \mathrm{CI}=0.56-215.51 ; \mathrm{p}=0.0511)$, but the statistical power of this finding is very low. This observation was on the border of statistical significance and this genotype combination was found out only in 4 samples, what is insufficient to assume any trends (Table 5).

\section{Discussion}

Although varicose veins pathogenesis is multifactorial, understanding of the genetic and 
Table 3. Characteristics of the study population.

\begin{tabular}{|c|c|c|c|c|c|}
\hline Characteristics & Cases & Controls & OR & $95 \%$ CI & $\mathbf{P}$ \\
\hline Total sample (females, males) & $138(90,48)$ & $138(90,48)$ & & & \\
\hline Family history: & & & 3.644 & $1.768-7.511$ & 0.0005 \\
\hline Father & $15(10.87 \%)$ & $4(2.90 \%)$ & & & \\
\hline Mother & $63(45.65 \%)$ & $14(10.14 \%)$ & & & \\
\hline Both parents & $28(20.29 \%)$ & $2(1.45 \%)$ & & & \\
\hline No history & $32(23.19 \%)$ & $22(15.94 \%)$ & & & \\
\hline No answer & None & $96(69.57 \%)$ & & & \\
\hline History of thrombosis & $23(16.67 \%)$ & None & 56.359 & $3.384-938.66$ & $<0.0001$ \\
\hline History of thrombophlebitis & $5(3.62 \%)$ & None & 11.412 & $0.6245-208.55$ & 0.0602 \\
\hline Working habits: & & & 45.060 & $10.704-189.69$ & $<0.0001$ \\
\hline Prolonged standing & $60(43.48 \%)$ & $39(28.26 \%)$ & & & \\
\hline Prolonged sitting & $32(23.19 \%)$ & $29(21.01 \%)$ & & & \\
\hline Both standing and sitting & $44(31.88 \%)$ & $15(10.87 \%)$ & & & \\
\hline$B M I:$ & & & 1.418 & $0.8826-2.279$ & 0.1849 \\
\hline 25.0-29.9 & $54(39.13 \%)$ & $32(23.19 \%)$ & & & \\
\hline $30.0-34.9$ & $14(10.14 \%)$ & $23(16.67 \%)$ & & & \\
\hline $35.0-39.9$ & $4(2.90 \%)$ & $4(2.90 \%)$ & & & \\
\hline$>40.0$ & None & $1(0.72 \%)$ & & & \\
\hline \multicolumn{6}{|l|}{ Females: } \\
\hline Hormonal contraception & $19(21.11 \%)$ & $9(10.00 \%)$ & 2.408 & $1.024-5.663$ & 0.0628 \\
\hline \multicolumn{6}{|l|}{ Number of deliveries: } \\
\hline 1 & $12(13.33 \%)$ & $12(13.33 \%)$ & & & \\
\hline 2 & $43(47.78 \%)$ & $39(43.33 \%)$ & & & \\
\hline 3 & $14(15.56 \%)$ & $13(14.44 \%)$ & & & \\
\hline 4 & $3(3.33 \%)$ & $3(3.33 \%)$ & & & \\
\hline 5 & $1(1.11 \%)$ & $1(1.11 \%)$ & & & \\
\hline Smoker & $22(15.94 \%)$ & $40(28.99 \%)$ & 0.4647 & $0.2587-0.8347$ & 0.0138 \\
\hline
\end{tabular}

environmental factors which contribute to their formation is limited (Fukaya et al. 2018). The known risk factors include older age, positive family history, thrombosis and thrombophlebitis, prolonged standing or sitting, elevated BMI, female gender, pregnancy and smoking (Raetz et al. 2019, Zolotukhin et al. 2017, Yun et al. 2018). Because our study is oriented on genetic factors contributing to the disease development, we wanted to eliminate the influence of environmental risk factors as much as possible. This selection could have resulted in a higher portion of smokers present in the control, even though smoking is well-known risk factor for varicose veins (Gourgou et al. 2002). Our results show a statistically significant correlation between positive family history and the risk of varicose veins $(\mathrm{p}=0.0005)$.

A possible role of $M M P 2$ (rs243866), MMP8 (rs11225395), MMP9 (rs3918242) polymorphisms in varicose veins development was evaluated by analyzing SNPs within the promoter region assumed to affect the gene expression. In our study, frequencies of alleles and genotypes of selected polymorphisms of $M M P 2, M M P 8$ and $M M P 9$ genes did not statistically significantly differ between the healthy controls and patients with varicose veins.

The role of polymorphism MMP2 rs243864 $(-1575 \mathrm{~A} / \mathrm{G})$ as a valuable marker for susceptibility to common genetically complex diseases is disputable, with both positive and negative findings. An association was reported in myocardial infarction (Peréz-Hernández et al. 2012), metabolic syndrome (Yadav et al. 2014) and colorectal cancer (Park et al. 2011). No association was observed with abdominal aortic aneurysm (Saracini et al. 
Table 4. Analysis of genotypes of polymorphisms MMP2 (rs243866), MMP8 (rs11225395), and MMP9 (rs3918242) in codominant, dominant and recessive genetic model.

\begin{tabular}{|c|c|c|c|c|c|c|c|c|}
\hline Polymorphism & Genetic model & $\begin{array}{c}\text { Case } \\
n=138(\%)\end{array}$ & $\begin{array}{c}\text { Controls } \\
\text { n=138 }(\%)\end{array}$ & SSD & $\mathbf{P}$ & $\chi^{2}$ & OR & $95 \%$ CI \\
\hline \multirow{10}{*}{$\begin{array}{l}M M P 2 \\
(r s 243866)\end{array}$} & Codominant: & & & & & & & \\
\hline & Genotype GG & $77(55.80)$ & $69(50.00)$ & & & & 1.00 & (Ref.) \\
\hline & Genotype GA & $52(37.68)$ & $62(44.93)$ & 1569.48 & 0.3100 & 1.0310 & 0.75 & $0.46-1.23$ \\
\hline & Genotype GG & $77(55.80)$ & $69(50.00)$ & & & & 1.00 & (Ref.) \\
\hline & Genotype AA & $9(6.52)$ & $7(5.07)$ & 17822.3 & 0.9974 & $1.0610^{\mathrm{E}-05}$ & 1.15 & $0.41-3.26$ \\
\hline & $\begin{array}{c}\text { Dominant: } \\
\text { Genotype GG }\end{array}$ & $77(55.80)$ & $69(50.00)$ & & & & 1.00 & (Ref.) \\
\hline & Genotype GA+AA & $61(44.20)$ & $69(50.00)$ & 2327.68 & 0.3986 & 0.7125 & 0.79 & $0.49-1.27$ \\
\hline & Recessive: & & & & & & & \\
\hline & Genotype GG+GA & $129(93.48)$ & $131(94.93)$ & & & & 1.00 & (Ref.) \\
\hline & Genotype AA & $9(6.52)$ & $7(5.07)$ & 8162.82 & 0.7967 & 0.0664 & 1.31 & $0.47-3.61$ \\
\hline \multirow{10}{*}{$\begin{array}{l}\text { MMP8 } \\
\text { (rs11225395) }\end{array}$} & Codominant: & & & & & & & \\
\hline & Genotype CC & $37(26.81)$ & $39(28.26)$ & & & & 1.00 & (Ref.) \\
\hline & Genotype CT & $80(57.97)$ & $71(51.45)$ & 1441.65 & 0.6380 & 0.2214 & 1.19 & $0.68-2.06$ \\
\hline & Genotype CC & $37(26.81)$ & $39(28.26)$ & & & & 1.00 & (Ref.) \\
\hline & Genotype TT & $21(15.22)$ & $28(20.29)$ & 2412.12 & 0.6498 & 0.2062 & 0.79 & $0.38-1.63$ \\
\hline & $\begin{array}{c}\text { Dominant: } \\
\text { Genotype CC }\end{array}$ & $37(26.81)$ & $39(28.26)$ & & & & 1.00 & (Ref.) \\
\hline & Genotype CT+TT & $101(73.19)$ & 99 (71.74) & 29825.67 & 0.8928 & 0.0182 & 1.08 & $0.63-1.82$ \\
\hline & Recessive: & & & & & & & \\
\hline & Genotype CC+CT & $117(84.78)$ & $110(79.71)$ & & & & 1.00 & (Ref.) \\
\hline & Genotype TT & $21(15.22)$ & $28(20.29)$ & 1781.69 & 0.3446 & 0.8933 & 0.71 & $0.38-1.32$ \\
\hline \multirow{10}{*}{$\begin{array}{l}\text { MMP9 } \\
(r s 3918242)\end{array}$} & Codominant: & & & & & & & \\
\hline & Genotype CC & $96(69.57)$ & $98(71.01)$ & & & & 1.00 & (Ref.) \\
\hline & Genotype CT & $37(26.81)$ & $37(26.81)$ & 369455.4 & 0.9399 & 0.0057 & 1.02 & $0.60-1.74$ \\
\hline & Genotype CC & $96(69.57)$ & $98(71.01)$ & & & & 1.00 & (Ref.) \\
\hline & Genotype TT & $5(3.62)$ & $3(2.17)$ & 3045.36 & 0.7183 & 0.1302 & 1.70 & $0.40-7.32$ \\
\hline & $\begin{array}{c}\text { Dominant: } \\
\text { Genotype CC }\end{array}$ & $96(69.57)$ & $98(71.01)$ & & & & 1.00 & (Ref.) \\
\hline & Genotype CT+TT & $42(30.43)$ & $40(28.99)$ & 31214.92 & 0.8952 & 0.0174 & 1.07 & $0.64-1.80$ \\
\hline & Recessive: & & & & & & & \\
\hline & Genotype $\mathrm{CC}+\mathrm{CT}$ & $133(96.38)$ & $135(97.83)$ & & & & 1.00 & (Ref.) \\
\hline & Genotype TT & $5(3.62)$ & $3(2.17)$ & 4206.99 & 0.7198 & 0.1287 & 1.69 & $0.40-7.22$ \\
\hline
\end{tabular}

2011) or rheumatoid arthritis (Nemec et al. 2006). We did not observe an association between polymorphism rs243864 and varicose veins risk. Peréz-Hernández et al. (2012) presume that the functional effect of this polymorphism may vary depending on the cell type.
Harendza et al. (2003) found out that in estrogen positive MCF-7 cells G allele showed increased, while A allele showed decreased transcriptional activity. On the other hand, Price et al. (2001) tried to search for naturally occurring polymorphisms within the promoter region of 
Table 5. Association of genotype combinations with development of varicose veins.

\begin{tabular}{|c|c|c|c|c|c|c|}
\hline $\begin{array}{l}\text { Genotype } \\
\text { combination }\end{array}$ & $\begin{array}{c}\text { Case } \\
n=138(\%)\end{array}$ & $\begin{array}{c}\text { Controls } \\
\mathrm{n}=138(\%)\end{array}$ & SSD & $\mathbf{P}$ & OR & $95 \%$ CI \\
\hline \multicolumn{7}{|c|}{$M M P 2+M M P 8$} \\
\hline$G G+C C$ & $20(14.49)$ & $15(10.87)$ & 1317.83 & & 1.00 & (Ref.) \\
\hline$G G+C T$ & $46(33.33)$ & $39(28.26)$ & 1298.28 & 0.8412 & 0.88 & $0.40-1.96$ \\
\hline$G G+T T$ & $11(7.97)$ & $15(10.87)$ & 1585.36 & 0.3056 & 0.55 & $0.20-1.54$ \\
\hline$G A+C C$ & $15(10.87)$ & $23(16.67)$ & 548.86 & 0.1627 & 0.49 & $0.19-1.24$ \\
\hline$G A+C T$ & $29(21.01)$ & $27(19.57)$ & 12083.79 & 0.6695 & 0.81 & $0.34-1.89$ \\
\hline$G A+T T$ & $8(5.80)$ & $12(8.70)$ & 1243.71 & 0.2695 & 0.50 & $0.16-1.53$ \\
\hline$A A+C C$ & $2(1.45)$ & $1(0.72)$ & 3122.84 & 1.0000 & 1.50 & $0.12-18.14$ \\
\hline$A A+C T$ & $5(3.62)$ & $5(3.62)$ & - & 0.7310 & 0.75 & $0.18-3.07$ \\
\hline$A A+T T$ & $2(1.45)$ & $1(0.72)$ & 3122.84 & 1.0000 & 1.50 & $0.12-18.14$ \\
\hline \multicolumn{7}{|c|}{$M M P 2+M M P 9:$} \\
\hline$G G+C C$ & $53(38.41)$ & $54(39.13)$ & 70963.96 & & 1.00 & (Ref.) \\
\hline$G G+C T$ & $21(15.22)$ & $14(10.14)$ & 669.25 & 0.3321 & 1.52 & $0.71-3.32$ \\
\hline$G G+T T$ & $3(2.17)$ & $1(0.72)$ & 996.58 & 0.6182 & 3.06 & $0.31-30.34$ \\
\hline$G A+C C$ & $36(26.09)$ & 40 (28.99) & 3725.91 & 0.8808 & 0.92 & $0.51-1.65$ \\
\hline$G A+C T$ & $15(10.87)$ & $20(14.49)$ & 1317.83 & 0.5610 & 0.76 & $0.35-1.65$ \\
\hline$G A+T T$ & $1(0.72)$ & $2(1.45)$ & 3122.84 & 1.0000 & 0.51 & $0.04-5.79$ \\
\hline$A A+C C$ & $7(5.07)$ & $4(2.90)$ & 1247.60 & 0.5292 & 1.78 & $0.49-6.45$ \\
\hline$A A+C T$ & $1(0.72)$ & $3(2.17)$ & 996.58 & 0.6187 & 0.34 & $0.03-3.37$ \\
\hline$A A+T T$ & $1(0.72)$ & $0(0.00)$ & 540.26 & 1.0000 & 3.06 & $0.12-76.76$ \\
\hline \multicolumn{7}{|c|}{$M M P 8+M M P 9:$} \\
\hline$C C+C C$ & $22(15.94)$ & $27(19.57)$ & 1741.94 & & 1.00 & (Ref.) \\
\hline$C C+C T$ & $11(7.97)$ & $12(8.70)$ & 22826.03 & 1.0000 & 1.13 & $0.42-3.04$ \\
\hline$C C+T T$ & $4(2.90)$ & $0(0.00)$ & 134.08 & 0.0511 & 11.00 & $0.56-215.51$ \\
\hline$C T+C C$ & $59(42.75)$ & $52(37.68)$ & 1465.39 & 0.3922 & 1.39 & $0.71-2.74$ \\
\hline$C T+C T$ & $20(14.49)$ & $17(12.32)$ & 3850.13 & 0.5139 & 1.44 & $0.61-3.41$ \\
\hline$C T+C C$ & $1(0.72)$ & $2(1.45)$ & 3122.84 & 1.0000 & 0.61 & $0.05-7.23$ \\
\hline$T T+C C$ & $15(10.87)$ & $19(13.77)$ & 2011.65 & 1.0000 & 0.96 & $0.40-2.34$ \\
\hline$T T+C T$ & $6(4.35)$ & $8(5.80)$ & 3580.85 & 1.0000 & 0.92 & $0.28-3.05$ \\
\hline$T T+T T$ & $0(0.00)$ & $1(0.72)$ & 540.26 & 1.0000 & 0.41 & $0.01-10.50$ \\
\hline
\end{tabular}

the $M M P 2$ gene and to analyze the effect of these variations on the gene expression. Authors reported that this polymorphism had no functional effect when tested within the background of estrogen receptor negative cells, including vascular smooth muscle cells (A10), monocyte/macrophage-like cell line (RAW264.7) and human embryonic kidney cells (293). We are not sure to what extent this could have influenced our results.

According to our present knowledge, there was no published study regarding the relation between polymorphism MMP8 $\mathrm{rs} 11225395 \quad(-790 \mathrm{C} / \mathrm{T})$ and varicose veins. But there were studies testing the relation of this polymorphism to the development of arterial hypertension in men (Moskalenko et al. 2019) or carotid atherosclerosis (Djurić et al. 2011). Also, several studies have reported that this SNP influences the MMP8 gene expression by alteration of its promoter activity. The $\mathrm{T}$ allele display higher promoter activity and protein expression than the $\mathrm{C}$ allele (Arechavaleta-Velasco et al. 2014, Feng et al. 2019, Decock et al. 2007, Dębniak et al. 2011, Wang et al. 2013). MMP-8 is overexpressed in long-lasting chronic venous ulcers. Chronic venous 
ulceration occurs only in $1 \%$ of the adult population in Western countries (Amato et al. 2015). Majority of patients enrolled in our study had varicose veins at CEAP stage $\mathrm{C} 2$. This could have influenced our results. It would be interesting to study the association of this polymorphism again with the group of C5-C6 patients.

Association of polymorphism MMP9 rs3918242 $(-1562 \mathrm{C} / \mathrm{T})$ and varicose veins is controversial. $\mathrm{Xu}$ et al. (2010) found out that the Callele in $M M P 9$ polymorphism (rs3918242) predisposes to varicose veins in the Chinese population $(\mathrm{P}<0.05)$ (patients $\mathrm{C} 3-\mathrm{C} 4)$. Previous studies show that $\mathrm{T}$ allele was associated with increased levels of MMP-9 in plasma (Raffetto and Khalil 2008, Xu et al. 2010). Kunt et al. (2015) obtained opposite results. Authors did not find out a statistically significant difference in allele or genotype distribution of MMP9 polymorphism in the Turkish population (patients C2-C4). Slonková et al. (2017) reported that MMP9 $1562 \mathrm{C} / \mathrm{T}$ alleles, as well as the distribution of genotypes, significantly differed between CVD patient (C2-C6) and control groups. The Tallele was observed more frequently in CVD patient group. We didn't obtain statistically significant results. Differences in these observations could have been influenced by various stages of CVD. SNPs are one of the numerous ways, through which the gene expression can be regulated.

TIMP-2 is an effective inhibitor of MMP-2 (Bourboulia and Stetler-Stevenson 2010). Kunt et al. (2015) observed an association of $\mathrm{C}$ allele of TIMP2 rs8179090 (-418 G/C) polymorphism and a higher risk for varicose veins $(p=0.007)$ in the Turkish population. The substitution of $\mathrm{G} \rightarrow \mathrm{C}$ allele may leads to lower transcription of TIMP2 gene (Mikołajczyk-Stecyna et al. 2015). On the other hand allele and genotype frequencies of TIMP2 (rs8179090) polymorphism were not significantly different between the patients with varicose veins and control group of Chinese origin $(p=0.069)$ (Xu et al. 2010). Several studies have demonstrated racial or ethnic differences in alleles and genotypes frequencies
(Hughes et al. 2006, Mattei et al. 2009). Due to the low frequency of a minor allele in the Slovak population, this polymorphism cannot serve as a marker for varicose veins development.

Unfortunately, none of our findings provide evidence that these polymorphisms are involved in the pathogenesis of varicose veins. Therefore, individually, they cannot serve as markers to this pathology. The analysis of genotypes combinations shows more promising results, although more data are needed.

\section{Conclusions}

Annually, varicose veins are diagnosed in $2.6 \%$ of women and $1.6 \%$ of men worldwide. The incidence of varicose veins (C2) is relatively variable (20\% to $64 \%$ ), the incidence of advanced stages of CVD (C3-C6) is approximately $5 \%$ (Wittens et al. 2015). Despite the fact that varicose veins and CVD are generally recognized as medical problem, their profound effects on patient's quality of life are largely underappreciated (Sutzko et al. 2018). Several studies have addressed this issue, effects of CVD and varicose veins on a patient's quality of life (Casana et al. 2018, Siribumrungwong et al. 2017, Onida and Davies 2016, Migdalski and Kuzdak 2015, Launois 2015).

Our analysis has not proven the association between selected polymorphisms and increased risk of varicose veins development in the Slovak population. More evidence with larger sample size is needed.

\section{Conflict of Interest}

There is no conflict of interest.

\section{Acknowledgements}

We would like to thank the staff of the Clinic of Surgery and Transplant Center of UH in Martin, ZILPO Ltd., GynMart Ltd., and JAVORKA Ltd., and their patients for participation in this study.

\section{References}

AMATO B, CORETTI G, COMPAGNA R, AMATO M, BUFFONE G, GIGLIOTTI D, GRANDE R, SERRA R, DE FRANCISCIS S: Role of matrix metalloproteinases in non-healing venous ulcers. Int Wound J 12: 641-645, 2015. https://doi.org/10.1111/iwj.12181

ARAVIND B, SAUNDERS B, NAVIN T, SANDISON A, MONACO C, PALEOLOG EM, DAVIES AH: Inhibitory effect of TIMP influences the morphology of varicose veins. Eur J Vasc Endovasc Surg 40: 754-765, 2010. https://doi.org/10.1016/j.ejvs.2010.04.028 
ARECHAVALETA-VELASCO F, CUEVAS-ANTONIO R, DOMINGUEZ-LOPEZ P, ESTRADA-MOSCOSO I, IMANI-RAZAVI FS, ZEFERINO-TOQUERO M, DIAZ-CUETO L: Matrix metalloproteinase-8 promoter gene polymorphisms in Mexican women with ovarian cancer. Med Oncol 31: 132, 2014. https://doi.org/10.1007/s12032-014-0132-3

BADIER-COMMANDER C, VERBEUREN T, LEBARD C, MICHEL JB, JACOB MP: Increased TIMP/MMP ratio in varicose veins: a possible explanation for extracellular matrix accumulation. J Pathol 192: 105-112, 2000. https://doi.org/10.1002/1096-9896(2000)9999:9999<::AID-PATH670>3.0.CO;2-1

BOURBOULIA D, STETLER-STEVENSON WG: Matrix metalloproteinases (MMPs) and tissue inhibitors of metalloproteinases (TIMPs): Positive and negative regulators in tumor cell adhesion. Semin Cancer Biol 20: 161-168, 2010. https://doi.org/10.1016/j.semcancer.2010.05.002

CASANA R, TOLVA VS, ODERO A JR, MALLOGGI C, PARATI G: Three-year follow-up and quality of life of endovenous radiofrequency ablation of the great saphenous vein with the ClosureFast ${ }^{\mathrm{TM}}$ procedure: Influence of BMI and CEAP class. Vascular 26: 498-508, 2018. https://doi.org/10.1177/1708538118762066

CHAMPELY S: pwr: Basic Functions for Power Analysis. R package version 1.3-0, 2020. https://CRAN.Rproject.org/package $=$ pwr

CHEN Y, PENG W, RAFFETTO JD, KHALIL RA: Matrix metalloproteinases in remodeling of lower extremity veins and chronic venous disease. Prog Mol Biol Transl Sci 147: 267-299, 2017. https://doi.org/10.1016/bs.pmbts.2017.02.003

DĘBNIAK T, JAKUBOWSKA A, SERRANO-FERNÁNDEZ P, KURZAWSKI G, CYBULSKI C, CHAUHAN SR, LAXTON RC, MALESZKA R, LUBINSKI J, YE S: Association of MMP8 gene variation with an increased risk of malignant melanoma. Melanoma Res 2011 21: 464-468. https://doi.org/10.1097/CMR.0b013e3283485fdd

DECOCK J, LONG JR, LAXTON RC, SHU XO, HODGKINSON C, HENDRICKX W, PEARCE EG, GAO YT, PEREIRA AC, PARIDAENS R, ZHENG W, YE S: Association of matrix metalloproteinase-8 gene variation with breast cancer prognosis. Cancer Res 67: 10214-10221, 2007. https://doi.org/10.1158/0008-5472.CAN-07$\underline{1683}$

DJURIĆ T, STANKOVIĆ A, KONČAR I, RADAK D, DAVIDOVIĆ L, ALAVANTIĆ D, ŽIVKOVIĆ M: Association of MMP 8 promoter gene polymorphisms with carotid atherosclerosis: preliminary study. Atherosclerosis 219: 673-678, 2011. https://doi.org/10.1016/j.atherosclerosis.2011.08.025

ELLINGHAUS E, ELLINGHAUS D, KRUSCHE P, GREINER A, SCHREIBER C, NIKOLAUS S, GIEGER C, STRAUCH K, LIEB W, ROSENSTIEL P, FRINGS N, FIEBIG A, SCHREIBER S, FRANKE A: Genomewide association analysis for chronic venous disease identifies EFEMP1 and KCNH8 as susceptibility loci. Sci Rep 7: 45652, 2017. https://doi.org/10.1038/srep45652

FENG J, CHEN Y, HUA W, SUN X, CHEN Y, LIU Y, FAN J, ZHAO Y, ZHAO L, XU X, YANG X: The MMP-8 rs11225395 promoter polymorphism increases cancer risk of non-asian populations: evidence from a metaanalysis. Biomolecules 9: pii: E570, 2019. https://doi.org/10.3390/biom9100570

FUKAYA E, FLORES AM, LINDHOLM D, GUSTAFSSON S, ZANETTI D, INGELSSON E, LEEPER NJ: Clinical and genetic determinants of varicose veins. Circulation 138: 2869-2880, 2018. https://doi.org/10.1161/CIRCULATIONAHA.118.035584

GOURGOU S, DEDIEU F, SANCHO-GARNIER H: Lower limb venous insufficiency and tobacco smoking: a case control study. Am J Epidemiol 155: 1007-1115, 2002. https://doi.org/10.1093/aje/155.11.1007

GÖRMÜS U, TIMIRCI-KAHRAMAN O, ERGEN A, KUNT AT, ISBIR S, DALAN AB, ISBIR T. Expression levels of elastin and related genes in human varicose veins. Folia Biol (Praha) 60: 68-73, 2014.

HARENDZA S, LOVETT DH, PANZER U, LUKACS Z, KUHNL P, STAHL RAK: Linked common polymorphisms in the gelatinase a promoter are associated with diminished transcriptional response to estrogen and genetic fitness. J Biol Chem 278: 20490-20499, 2003. https://doi.org/10.1074/jbc.M211536200

HU X, HU F, XU Y, TANG J, CHU H, ZHONG Y: Disequilibrium in MMPs and the tissue inhibitor of metalloproteinases in different segments of the varicose great saphenous vein wall. Int Angiol 38: 185-193, 2019. https://doi.org/10.23736/S0392-9590.19.04144-0 
HUGHES LB, BEASLEY TM, PATEL H, TIWARI HK, MORGAN SL, BAGGOTT JE, SAAG KG, MCNICHOLL J, MORELAND LW, ALARCÓN GS, BRIDGES SL JR: Racial or ethnic differences in allele frequencies of single-nucleotide polymorphisms in the methylenetetrahydrofolate reductase gene and their influence on response to methotrexate in rheumatoid arthritis. Ann Rheum Dis 65: 1213-1218, 2006. https://doi.org/10.1136/ard.2005.046797

JOHNSON JL: Metalloproteinases in atherosclerosis. Eur J Pharmacol 816: 93-106, 2017. https://doi.org/10.1016/j.ejphar.2017.09.007

KALININ RE, SUCHKOV IA, PSHENNIKOV AS, KAMAEV AA, MZHAVANADZE ND: Concentration of matrix metalloproteinases and magnesium ions in patients with varicose veins of lower limbs. (Article in Russian) Angiol Sosud Khir 22: 24-28, 2016.

KUNT AT, ISBIR S, GÖRMUS U. Polymorphisms of MMP9 and TIMP2 in patients with varicose veins. In Vivo 29: 461-465, 2015.

LAUHIO A, FÄRKKILÄ E, PIETILÄINEN KH, ÅSTRÖM P, WINKELMANN A, TERVAHARTIALA T, PIRILÄ E, RISSANEN A, KAPRIO J, SORSA TA, SALO T: Association of MMP-8 with obesity, smoking and insulin resistance. Eur J Clin Invest 46: 757-765, 2016. https://doi.org/10.1111/eci.12649

LAUNOIS R: Health-related quality-of-life scales specific for chronic venous disorders of the lower limbs. J Vasc Surg Venous Lymphat Disord 3: 219-227, 2015. https://doi.org/10.1016/j.jvsv.2014.08.005

MACCOLL E, KHALIL RA: Matrix metalloproteinases as regulators of vein structure and function: implications in chronic venous disease. J Pharmacol Exp Ther 355: 410-428, 2015. https://doi.org/10.1124/jpet.115.227330

MATTEI J, PARNELL LD, LAI CH-Q, GARCIA-BAILO B, ADICONIS X, SHEN J, ARNETT D, DEMISSIE S, TUCKER KL, ORDOVAS JM: Disparities in allele frequencies and population differentiation for 101 diseaseassociated single nucleotide polymorphisms between Puerto Ricans and non-Hispanic whites. BMC Genet 10: 45, 2009. https://doi.org/10.1186/1471-2156-10-45

MIGDALSKI $€$, KUZDAK K: The use of the VEINES-QOL/Sym questionnaire in patients operated for varicose veins. Pol Przegl Chir 87: 491-498, 2015. https://doi.org/10.1515/pjs-2015-0094

MIKOŁAJCZYK-STECYNA J, KORCZ A, GABRIEL M, PAWLACZYK L, OSZKINIS G, SŁOMSKI R: Gene polymorphism $-418 \mathrm{G} / \mathrm{C}$ of tissue inhibitor of metalloproteinases 2 is associated with abdominal aortic aneurysm. J Vasc Surg 61: 1114-1119, 2015. https://doi.org/10.1016/j.jvs.2013.12.045

MOSKALENKO MI, MILANOVA SN, PONOMARENKO IV, POLONIKOV AV, CHURNOSOV MI: Study of associations of polymorphism of matrix metalloproteinases genes with the development of arterial hypertension in men. Kardiologiia 59 (7S): 31-39, 2019. https://doi.org/10.18087/cardio.2598

NAGASE H, VISSE R, GILLIAN MURPHY G: Structure and function of matrix metalloproteinases and TIMPs. Cardiovasc Res 69: 562-573, 2006. https://doi.org/10.1016/j.cardiores.2005.12.002

NEMEC P, GOLDBERGOVA M, SWOBODNIK T, POLASKOVA D, SOUCEK M, VASKU A: Polymorphism of gene promotor region for MMP-2 in rheumatoid arthritis. (Article in Czech) Vnitr Lek 52: 348-354, 2006.

ONIDA S, DAVIES AH: Predicted burden of venous disease. Phlebology 31 (Suppl 1): 74-79, 2016. https://doi.org/10.1177/0268355516628359

PARK KS, KIM SJ, KIM KH, KIM JC: Clinical characteristics of TIMP2, MMP2, and MMP9 gene polymorphisms in colorectal cancer. J Gastroenterol Hepatol 26: 391-397, 2011. https://doi.org/10.1111/j.1440-1746.2010.06504.x

PÉREZ-HERNÁNDEZ N, VARGAS-ALARCÓN G, MARTÍNEZ-RODRÍGUEZ N, MARTÍNEZ-RÍOS MA, PEÑA-DUQUE MA, PEÑA-DÍAZ ADE L, VALENTE-ACOSTA B, POSADAS-ROMERO C, MEDINA A, RODRÍGUEZ-PÉREZ JM: The matrix metalloproteinase 2-1575 gene polymorphism is associated with the risk of developing myocardial infarction in Mexican patients. J Atheroscler Thromb 19: 718-727, 2012. https://doi.org/10.5551/jat.11817

PRICE SJ, GREAVES DR, WATKINS H: Identification of novel, functional genetic variants in the human matrix metalloproteinase-2 gene: role of Sp1 in allele-specific transcriptional regulation. J Biol Chem 276: 7549-7558, 2001. https://doi.org/10.1074/jbc.M010242200

RABE E, PANNIER F: Societal costs of chronic venous disease in CEAP C4, C5, C6 disease. Phlebology 25 (Suppl 1): 64-67, 2010. https://doi.org/10.1258/phleb.2010.010s09

RAETZ J, WILSON M, COLLINS K: Varicose veins: Diagnosis and treatment. Am Fam Physician 99: 682-688, 2019. 
RAFFETTO JD, KHALIL RA: Matrix metalloproteinases and their inhibitors in vascular remodeling and vascular disease. Biochem Pharmacol 75: 346-359, 2008. https://doi.org/10.1016/j.bcp.2007.07.004

R CORE TEAM: R: A language and environment for statistical computing. R Foundation for Statistical Computing, Vienna, Austria, 2020. URL https://www.R-project.org/.

SALMHOFER W: Ätiologie, nomenklatur und pathophysiologie der chronisch venösen Insuffizienz. (Article in German) Wien Med Wochenschr 166: 264-269, 2016. https://doi.org/10.1007/s10354-016-0466-X

SARACINI C, BOLLI P, STICCHI E, PRATESI G, PULLI R, SOFI F, PRATESI C, GENSINI GF, ABBATE R, GIUSTI B: Polymorphisms of genes involved in extracellular matrix remodeling and abdominal aortic aneurysm. J Vasc Surg 55: 171-179, 2012. https://doi.org/10.1016/j.jvs.2011.07.051

SEO DW, LI H, GUEDEZ L, WINGFIELD PT, DIAZ T, SALLOUM R, WEI BY, STETLER-STEVENSON WG: TIMP 2 mediated inhibition of angiogenesis: an MMP-independent mechanism. Cell 114: 171-180, 2003. https://doi.org/10.1016/S0092-8674(03)00551-8

SLONKOVÁ V, SLONKOVÁ V JR, VAŠKU゚ A, VAŠKŮ V: Genetic predisposition for chronic venous insufficiency in several genes for matrix metalloproteinases (MMP-2, MMP-9, MMP-12) and their inhibitor TIMP-2. J Eur Acad Dermatol Venereol 31: 1746-1752, 2017. https://doi.org/10.1111/jdv.14447

SERRALHEIRO P, NOVAIS A, CAIRRÃO E, MAIA C, COSTA ALMEIDA CM, VERDE I: Variability of MMP/TIMP and TGF- $\beta 1$ receptors throughout the clinical progression of chronic venous disease. Int J Mol Sci 19: piiE6, 2017. https://doi.org/10.3390/ijms19010006

SHIOMI T, LEMAÎTRE V, D'ARMIENTO J, OKADA Y: Matrix metalloproteinases, a disintegrin and metalloproteinases, and a disintegrin and metalloproteinases with thrombospondin motifs in non-neoplastic diseases. Pathol Int 60: 477-496, 2010. https://doi.org/10.1111/j.1440-1827.2010.02547.x

SIRIBUMRUNGWONG B, NOORIT P, WILASRUSMEE C, TEERAWATTANANON Y, THAKKINSTIAN A: Quality of life after great saphenous vein ablation in Thai patients with great saphenous vein reflux. Asian J Surg 40: 295-300, 2017. https://doi.org/10.1016/j.asjsur.2015.10.004

SUTZKO DC, OBI AT, KIMBALL AS, SMITH ME, WAKEFIELD TW, OSBORNE NH: Clinical outcomes after varicose vein procedures in octogenarians within the Vascular Quality Initiative Varicose Vein Registry. J Vasc Surg Venous Lymphat Disord 6: 464-470, 2018. https://doi.org/10.1016/j.jvsv.2018.02.008

ŠTVRTINOVÁ V, ČELOVSKÁ D: Dokáže edukácia obyvatel'stva zniźžit výskyt kŕčových žíl a ich komplikácií na Slovensku? (Article in Slovak) Vask Med 9: 18-21, 2017.

WANG XZ, DU XM, JING QM, LI XX, GU RX, WANG J, HAN YL: Impact of matrix metalloproteinase-8 gene variations on the risk of thoracic aortic dissection in a Chinese Han population. Mol Biol Rep 40: 5953-5958, 2013. https://doi.org/10.1007/s11033-013-2704-2

WITTENS C, DAVIES AH, BÆKGAARD N, BROHOLM R, CAVEZZI A, CHASTANET S, DE WOLF M, EGGEN C, GIANNOUKAS A, GOHEL M, KAKKOS S, LAWSON J, NOPPENEY T, ONIDA S, PITTALUGA P, THOMIS S, TOONDER I, VUYLSTEKE M, ESVS GUIDELINES COMMITTEE, ET AL.: Editor's choice e management of chronic venous disease: Clinical practice guidelines of the European Society for Vascular Surgery (ESVS). Eur J Vasc Endovasc Surg 49: 678-737, 2015. https://doi.org/10.1016/j.ejvs.2015.02.007

XU HM, ZHAO Y, ZHANG XM, ZHU T, FU WG: Polymorphisms in MMP-9 and TIMP-2 in Chinese patients with varicose veins. J Surg Res 168: E143-E148, 2011. https://doi.org/10.1016/j.jss.2010.11.002

YADAV SS, MANDAL RK, SINGH MK, USMAN K, KHATTRI S: Genetic variants of matrix metalloproteinase (MMP2) gene influence metabolic syndrome susceptibility. Genet Test Mol Biomarkers 18: 88-92, 2014. https://doi.org/10.1089/gtmb.2013.0361

YUN MJ, KIM YK, KANG DM, KIM JE, HA WC, JUNG KY, CHOI HW: A study on prevalence and risk factors for varicose veins in nurses at a university hospital. Saf Health Work 9: 79-83, 2018. https://doi.org/10.1016/j.shaw.2017.08.005

ZHAO M-Y, ZHAO T, MENG Q-Y, ZHAO L, LI X-C: Estrogen and estrogen receptor affects MMP2 and MMP9 expression through classical ER pathway and promotes migration of lower venous vascular smooth muscle cells. Eur Rev Med Pharmacol Sci 24: 1460-1467, 2020. https://doi.org/10.26355/eurrev_202002_20205 
ZOLOTUKHIN IA, SELIVERSTOV EI, SHEVTSOV YN, AVAKIANTS IP, NIKISHKOV AS, TATARINTSEV AM, KIRIENKO AI: Prevalence and risk factors for chronic venous disease in the general Russian population. Eur J Vasc Endovasc Surg 54: 752-758, 2017. https://doi.org/10.1016/j.ejvs.2017.08.033 